\title{
Simultaneous ammonium and nitrate removal by a modified intermittently aerated sequencing batch reactor (SBR) with multiple filling events
}

\author{
Mehdi Hajsardar ${ }^{1}$, Seyed Mehdi Borghei ${ }^{2}$, Amir Hessam Hassani ${ }^{1}$, Afshin Takdastan ${ }^{3}$ \\ ${ }^{1}$ Islamic Azad University, Department of Environmental Engineering, Science and Research Branch, Tehran, Iran, Postal \\ code: 1477893855 \\ ${ }^{2}$ Sharif University of Technology, Department of Chemical and Petroleum Engineering, Tehran, Iran, Postal code: 11365/8639 \\ ${ }^{3}$ Ahvaz Jundishapur University of Medical Sciences, Environmental Technologies Research Center, Ahvaz, Iran, Postal \\ code: 6135715794 \\ "Corresponding author: e-mail: mborghei@sharif.edu
}

\begin{abstract}
Optimized methods for simultaneous removal of nitrate, nitrite and ammonium are important features of nutrient removal. Nitrogen removal efficiency in an intermittently aerated sequencing batch reactor (IA-SBR) with multiple filling events was studied. No external carbon source was added and three filling events were considered. Oxidationreduction potential (ORP) and $\mathrm{pH}$ curve at solids retention time (SRT) of $20 \mathrm{~d}$ were analyzed. Effects of three organic loading rates (OLR), 0.67, 1.0 and $1.5 \mathrm{kgCOD} / \mathrm{m}^{3} \mathrm{~d}$, and three nitrogen loading rates (NLR), 0.054, 0.1 and $0.15 \mathrm{kgN} / \mathrm{m}^{3} \mathrm{~d}$, on nitrogen removal were studied. Nitrate Apex in $\mathrm{pH}$ curve and Nitrate Knee in ORP profile indicated that the end of denitrification would be achieved sooner. The kinetic coefficients of endogenous decay $\left(\mathrm{k}_{\mathrm{d}}\right)$ and yield $(\mathrm{Y})$ were identified to evaluate heterotrophic specific denitrification rate $\left(\mathrm{SDNR}_{\mathrm{b}}\right)$. In period 2 at NLR of $0.054 \mathrm{kgN} / \mathrm{m}^{3} \mathrm{~d}$ and considering 2 anoxic and 3 aerobic phases, nitrogen removal efficiency was $91.43 \%$.
\end{abstract}

Keywords: denitrification, intermittent aeration, filling event, oxidation-reduction potential, sequencing batch reactor.

\section{INTRODUCTION}

Removal of nutrients, namely nitrogen and phosphorus compounds, is one of the major objectives of wastewater treatment. High levels of nutrients in wastewater effluent are known to be the main cause of eutrophication, foaming and oxygen depletion in surface waters ${ }^{1-2}$. Biological nitrification is a natural aerobic reaction requiring reasonable amounts of oxygen to complete. The result is reduction of dissolved oxygen (DO) in receiving water bodies. Nitrogen removal may be carried out by chemical or biological processes ${ }^{3}$. In modern wastewater treatment facilities, the emphasis is on removal of nutrients by biological methods ${ }^{4}$, considered to be more effective and economical ${ }^{5}$. This type of treatment plants, known as BNR (biological nutrient removal) plants are designed in many variations. A well known biological system for nitrogen removal is Sequencing Batch Reactor (SBR $)^{6-7}$.

SBR incorporates a batch reactor for aerating and biomass separation in a single tank. The process therefore consists of four stages including filling, aerating, settling, and decanting of wastewater ${ }^{8-9}$.

In comparison with different processes, SBR has high flexibility and the process has considerable potential for nutrient removal from wastewater. In this system nitrifying, denitrifying, and phosphorus removing bacteria grow in the same reactor. The growth of these three kinds of microorganisms could be achieved by correct timing and alternating aeration strategy in a single reactor ${ }^{10,11}$.

Nitrification is an aerobic process in which ammonium $\left(\mathrm{NH}_{4}^{+}\right)$is oxidized to nitrite $\left(\mathrm{NO}_{2}^{-}\right)$which is further oxidized to nitrate $\left(\mathrm{NO}_{3}{ }^{-}\right)$. Nitrification is a two-step process that is described in equations 1 and $2^{12}$. Further, equation 3 describes total oxidation - reduction of nitrification ${ }^{4}$.

$\mathrm{NH}_{4}{ }^{+}+\frac{3}{2} \mathrm{O}_{2} \rightarrow \mathrm{NO}_{2}^{-}+\mathrm{H}_{2} \mathrm{O}+2 \mathrm{H}^{+}$

$$
\begin{aligned}
& \mathrm{NO}_{2}{ }^{-}+\frac{1}{2} \mathrm{O}_{2} \rightarrow \mathrm{NO}_{3}^{-} \\
& \mathrm{NH}_{4}{ }^{+}+2 \mathrm{O}_{2} \rightarrow \mathrm{NO}_{3}^{-}+2 \mathrm{H}^{+}+\mathrm{H}_{2} \mathrm{O}
\end{aligned}
$$

Denitrification occurs under anoxic condition through which nitrate is reduced to nitric oxide (NO), nitrous oxide $\left(\mathrm{N}_{2} \mathrm{O}\right)$, and then nitrogen gas $\left(\mathrm{N}_{2}\right)$. All the reactions of the nitrate reduction to nitrogen gas are demonstrated in equation $4^{13}$.

$\mathrm{NO}_{3}{ }^{-} \rightarrow \mathrm{NO}_{2}{ }^{-} \rightarrow \mathrm{NO} \rightarrow \mathrm{N}_{2} \mathrm{O} \rightarrow \mathrm{N}_{2}$

BNR plants provide alternatively oxic and anoxic conditions to achieve nitrification and denitrification. SBR system can be operated under these conditions in one tank through variation of the number of cycles per day and step feeding, 14-15. Without operation under anoxic condition, nitrate would be present in the effluent of the reactor. Operating SBR under both aerobic and anoxic conditions results in nitrate removal during anoxic phase. Denitrification requires a carbon source that should be added to the reactor. The carbon source is necessary for heterotrophic bacteria to thrive. External carbon source is added from outside the treatment process. Ethanol, methanol, acetate, acetic acid, glycerol, molasses are commonly used as external carbon sources. Internal carbon source is organic carbon materials obtained either from materials stored within the cells (endogenous carbon sources) or within the influent wastewater ${ }^{16}$.

Nitrogen mass balance during a cycle of SBR implicates that increasing the number of filling events during a cycle decreases total nitrogen concentration in the effluent (equation 5) ${ }^{17}$.

$N_{E F}=N_{I N} \cdot \frac{V_{F}}{V_{T}} \cdot \frac{1}{M}$

where:

$\mathrm{N}_{\mathrm{EF}}$ : Nitrogen concentration in the effluent, $\mathrm{mg} / \mathrm{l}$ $\mathrm{N}_{\mathrm{IN}}$ : Nitrogen concentration in the influent, $\mathrm{mg} / \mathrm{l}$ 
$\mathrm{V}_{\mathrm{F}} / \mathrm{V}_{\mathrm{T}}$ : The ratio between fill volume and total reactor volume

M: The number of filling events during one cycle

By intermittent aeration, the processes of nitrification and denitrification would be achieved. Considering multiple filling events of SBR for providing internal carbon source, there are two orders for aerobic and anoxic conditions. When aerobic-anoxic sequence is planned, because of nitrification in aerobic phase, ammonium is oxidized to nitrate. This conversion is accomplished by ammonium oxidizing bacteria (AOB) and nitrite oxidizing bacteria (NOB). At the start of anoxic phase wastewater is added to the reactor and at the end of the cycle, ammonium is present in the effluent. When anoxic-aerobic sequence is maintained, ammonium concentration is high at the end of anoxic phase but nitrification process under aerobic condition decreases ammonium. In the latter sequence, nitrate level in the aerobic condition is increased. Therefore, intermittent aeration through aerobic-anoxic-aerobic sequence can be a useful method to achieve the advantages of both orders. Because of economic and operational reasons, the number of the reactors is an important factor for nitrogen removal objectives. It is important to achieve aerobic and anoxic conditions in a single tank. For example a modified SBR with different aerobic, anaerobic and anoxic conditions was used in a research for nitrogen removal but this strategy required $4 \operatorname{tanks}^{18}$. Simultaneous nitrification and denitrification (SND) takes place in a single reactor but fixed biofilm carriers should be added to the reactor to provide aerobic and anoxic zones $^{19,20}$. Another single-step process is oxygen-limited autotrophic nitrification-denitrification (OLAND) in which ammonium is oxidized to nitrite and then nitrite is reduced to nitrogen gas. In second step of OLAND a portion of ammonium is used as electron donor. This process required biofilm carriers, too. Other novel processes including completely autotrophic nitrogen removal over nitrite (CANON), anaerobic ammonium oxidation (ANAMMOX) and simultaneous nitrification-anammoxdenitrification (SNAD), require the activity of anaerobic microorganisms in a part of the processes ${ }^{\mathbf{2 1}}$.

In this study a modified intermittently aerated (IA) SBR was studied for nitrogen removal. By operating multiple filling events under anoxic condition, wastewater was added as internal carbon source. Both nitrification and denitrification processes were achieved in a single laboratory-scale tank, alternately. The timing of the proposed operation may be difficult in a real size system but many other researchers surveyed novel nitrogen removal methods in full-scale $\mathrm{SBR}^{22-24}$. In a domestic wastewater treatment plant (WWTP) the choice of carbon source depends on safety, cost, ease of use as well as the compatibility of the materials. Furthermore, supplemental carbon feed points is required ${ }^{\mathbf{1 6}}$. Operating multiple filling events as a means for adding internal carbon source would be an alternative to reduce these difficulties.

\section{MATERIAL AND METHODS}

\section{Laboratory-Scale SBR}

A cylindrical tank made of Plexiglas was used as a laboratory-scale SBR (Table 1). Normally closed solenoid valves were used for drawing excess sludge and effluent. Feeding was introduced into the reactor from the top. Samplers were installed at different heights of the reactor to collect proper samples for determination of the concentration of effluent parameters and solids retention time (SRT). An aquarium heater was installed for temperature adjustment. Two aquarium pumps (double outlet with maximum flow rate of $5.5 \mathrm{l} / \mathrm{min}$ ) were used as aerators where air was supplied from top and bottom of the reactor through air stones. Figure 1 shows a schematic representation of the reactor.

Table 1. SBR properties

\begin{tabular}{|l|c|}
\hline Material & Plexiglas \\
\hline Shape & Cylindrical \\
\hline Diameter [m] & 0.24 \\
\hline Height [m] & 0.68 \\
\hline Total volume [L] & 31 \\
\hline Working volume [L] & 28 \\
\hline feed volume per cycle [L] & 19 \\
\hline $\begin{array}{l}\text { Remaining wastewater from } \\
\text { previous cycle [L] }\end{array}$ & 8 \\
\hline $\begin{array}{l}\text { effluent volume after a cycle } \\
\text { [L] }\end{array}$ & 19 \\
\hline $\begin{array}{l}\text { excess sludge volume after } \\
\text { a cycle [L] }\end{array}$ & 1 \\
\hline
\end{tabular}

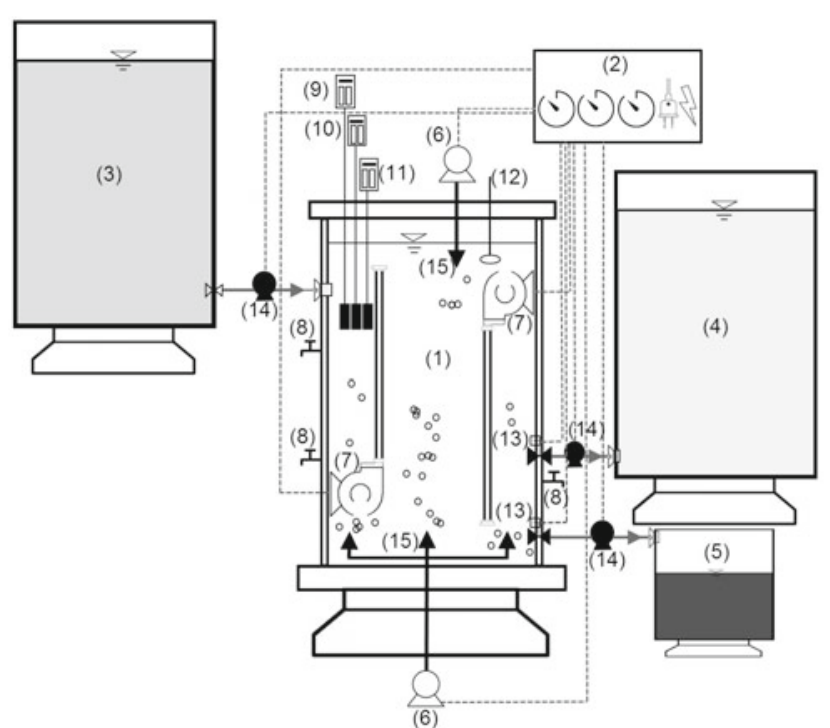

Figure 1. Schematic diagram of the sequencing batch reactor. 1. reactor; 2. control system; 3. influent tank; 4. effluent tank; 5. sludge tank; 6. aerators; 7. recirculating pump; 8. sampler; 9. ORP meter; 10. DO meter; 11. $\mathrm{pH}$ meter; 12 . heater; 13 . solenoid valves; 14 . peristaltic pump; 15. air stone

\section{Operation}

A control system including three analog timers (theben AG, Model, SUL 181 d, Germany), a contactor (Schneider Electric, Model, LC1D18, Germany) and two relays (Finder, Model, 60.13.8.230.0040, Europe) was utilized to provide the cycles of SBR. Solenoid valves, aerators and recirculating pumps were controlled by the timers. Each cycle of SBR lasted for 24 hours while the timers 
provided aerobic and anoxic phases for nitrification and denitrification, respectively. During anoxic phase recirculating pumps were employed to achieve complete mix conditions in the reactor. SBR pilot operated during 2 different operational periods. The number of filling events in Period 1 was 2, whereas period 2 contained 3 filling events. Besides, a blank reactor was operated under same aerobic and anoxic conditions. The blank had one filling event. Figure 2 describes the schedules of blank and test reactors.
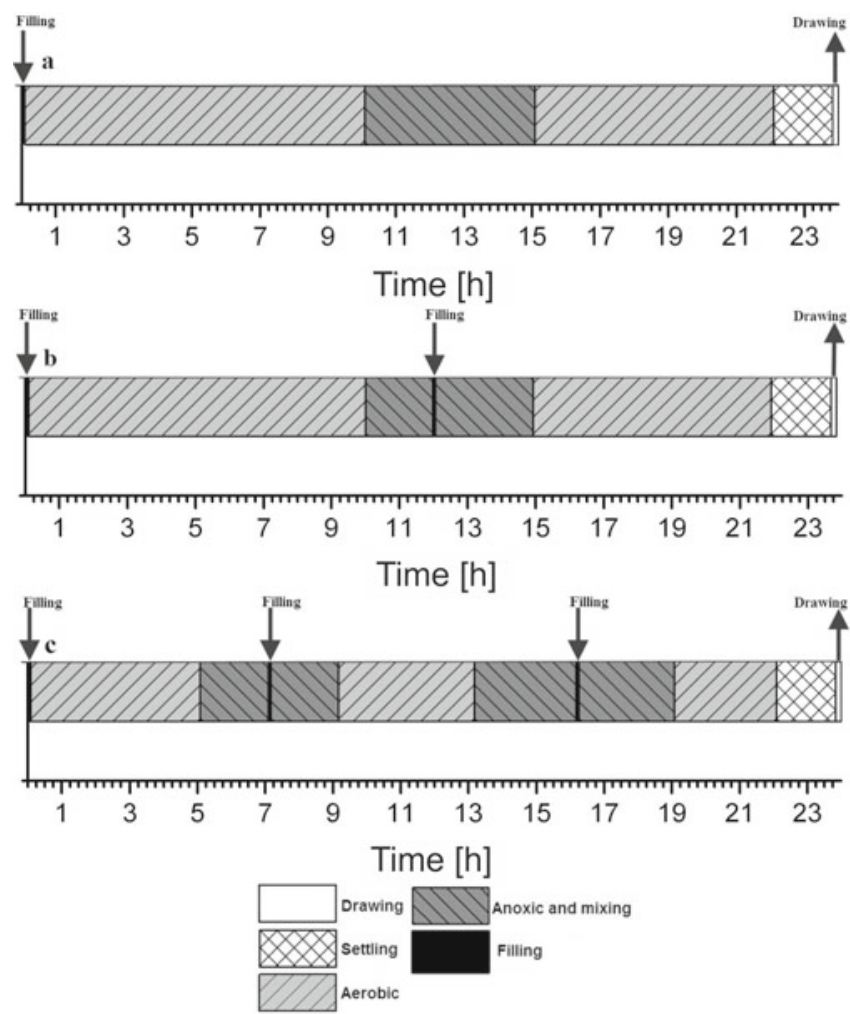

Figure 2. Timing of SBR; a: blank reactor, b: test reactor during period 1 , c: test reactor during period 2

\section{Reactor start-up}

At the beginning of experimental study the seed of activated sludge $(5 \mathrm{~L})$ was brought from Choneybeh WWTP (Ahvaz, Iran). 30 days was needed for microorganisms to adapt to new environment. Synthetic wastewater was used to fill the reactor in a few days. Dry milk was used as the source of carbon, amino acids as well as vitamins. Ammonium chloride $\left(\mathrm{NH}_{4} \mathrm{CL}\right)$ was added to synthetic wastewater as the source of ammonium while urea $\left(\mathrm{CO}\left(\mathrm{NH}_{2}\right)_{2}\right)$ was used as the source of organic nitrogen. Also, potassium dihydrogen phosphate $\left(\mathrm{KH}_{2} \mathrm{PO}_{4}\right)$ was added as the source of phosphorus. The characteristics of one liter of synthetic wastewater and wastewater composition are presented in Table 2 and Table 3, respectively. The Effluent chemical oxygen demand (COD) was the indicator of the effluent steady state flow. Figure 3 shows the relationship between SRT and COD removal efficiency before reaching steady state flow. Carbon/Nitrogen $(\mathrm{C} / \mathrm{N})$ and fill volume/total reactor volume $\left(\mathrm{V}_{\mathrm{F}} / \mathrm{V}_{\mathrm{T}}\right)$ ratios were 12.5 and 0.61 , respectively. Approximately, DO level in anoxic phase was kept to 0.2
Table 3. Synthetic wastewater composition

\begin{tabular}{|l|c|c|c|c|}
\hline $\begin{array}{l}\text { Distilled } \\
\text { Water } \\
{[\mathrm{L}]}\end{array}$ & $\begin{array}{c}\text { Dry } \\
\text { Milk } \\
{[\mathrm{gr}]}\end{array}$ & $\begin{array}{c}\mathrm{NH}_{4} \mathrm{CL} \\
{[\mathrm{gr}]}\end{array}$ & $\begin{array}{c}\mathrm{CO}\left(\mathrm{NH}_{2}\right)_{2} \\
{[\mathrm{gr}]}\end{array}$ & $\begin{array}{c}\mathrm{KH}_{2} \mathrm{PO} 4 \\
{[\mathrm{gr}]}\end{array}$ \\
\hline 1 & 1.6 & 0.056 & 0.030 & 0.011 \\
\hline
\end{tabular}

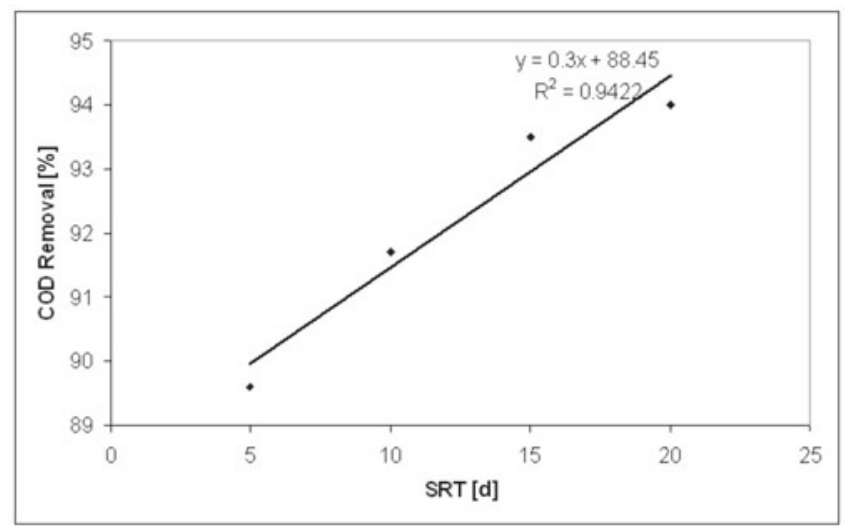

Figure 3. SRT vs. COD removal efficiency

$\mathrm{gram} / \mathrm{m}^{3}$ of the reactor working volume or less. Hence, DO level in aerobic and anoxic phases of IA reactor were 3 and $0 \mathrm{mg} / \mathrm{l}$, respectively. The reactor temperature was kept at $20^{\circ} \mathrm{C}$. IA reactor could be operated at SRT of 18-40 $\mathrm{d}$ and hydraulic retention time (HRT) of above $16 \mathrm{~h}(0.67 \mathrm{~d})^{4}$. In this study the reactor was operated at HRT of $1.47 \mathrm{~d}$ and SRT was $20 \mathrm{~d}$.

\section{Analytical methods}

Total suspended solids (TSS), mixed liquor suspended solids (MLSS), volatile suspended solids (VSS) and COD were measured according to the standard methods for the examination of water and wastewate ${ }^{25}$. Ammonium, nitrate, and nitrite were determined with a spectrophotometer (HACH, Model DR 5000, U.S.A). Total kjeldahl nitrogen (TKN) determination was achieved using a set of units. After digestion of samples by infra-red rapid digestor (behr Labor-Technik GmbH, Model, behrotest ${ }^{\circledR}$ InKjel $450 \mathrm{P}$, Germany), measurement was continued using a steam distillation unit (behr Labor-Technik GmbH, Model, behrotest ${ }^{\circledR}$ S4 Germany). The distillate was collected in boric acid $\left(\mathrm{H}_{3} \mathrm{BO}_{3}\right)$. Manual titration which used sulfuric acid $\left(\mathrm{H}_{2} \mathrm{SO}_{4}\right)$ as titrant was carried out until the indicator turned pale lavender. Nitrogen compounds measurement was based on the details of Table 4. DO was measured with a portable DO Meter (WTW GmbH, Model, ProfiLine Oxi 3210, Germany) and $\mathrm{pH}$ was measured with a portable $\mathrm{pH}$ meter (HANNA instruments, Model, HI 991001, U.S.A). An oxidation-reduction potential (ORP) meter (EUTECH, Model, Oakton ORPTestr 10, Singapore) was employed for determination of ORP.

\section{RESULTS AND DISCUSSION}

The results of the experimental operations of the blank, and test reactor during period 1 and period 2 are presented in Table 5 .

Table 2. Synthetic wastewater characteristics

\begin{tabular}{|l|c|c|c|c|c|c|c|}
\hline $\operatorname{COD}[\mathrm{mg} / \mathrm{L}]$ & $\mathrm{TN}[\mathrm{mg} / \mathrm{L}]$ & $\begin{array}{c}\mathrm{TKN} \\
{[\mathrm{mg} / \mathrm{L}]}\end{array}$ & $\begin{array}{c}\mathrm{NH}_{4}^{+} \\
{[\mathrm{mg} / \mathrm{L}]}\end{array}$ & $\begin{array}{c}\text { Org-N } \\
{[\mathrm{mg} / \mathrm{L}]}\end{array}$ & $\begin{array}{c}\mathrm{NO}_{3}^{-} \\
{[\mathrm{mg} / \mathrm{L}]}\end{array}$ & $\begin{array}{c}\mathrm{NO}_{2}^{-} \\
{\left[\mathrm{mg}^{-} / \mathrm{L}\right]}\end{array}$ & $\begin{array}{c}\mathrm{PO}_{4}{ }^{3-} \\
{[\mathrm{mg} / \mathrm{L}]}\end{array}$ \\
\hline 1000 & 80 & 79 & 50 & 29 & 0.5 & 0.1 & 10 \\
\hline
\end{tabular}


Table 4. General results of the blank and test reactor

\begin{tabular}{|l|c|c|c|c|c|c|c|}
\hline Measuring method & Parameter & $\begin{array}{c}\text { Accuracy } \\
\text { measurement } \\
\text { method }\end{array}$ & $\begin{array}{c}\text { Volume of } \\
\text { sample } \\
\text { [ml] }\end{array}$ & $\begin{array}{c}\text { The } \\
\text { result unit }\end{array}$ & $\begin{array}{c}\text { Sampling } \\
\text { frequency }\end{array}$ & $\begin{array}{c}\text { Sampler } \\
\text { point }\end{array}$ & $\begin{array}{c}\text { The number of } \\
\text { repetition }\end{array}$ \\
\hline $\begin{array}{l}\text { Cadmium } \\
\text { reduction }\end{array}$ & Nitrate & MMSE & 10 & $\mathrm{mg} / \mathrm{l}$ & $\begin{array}{c}25 \text { times per } \\
\text { day }\end{array}$ & $\begin{array}{c}\text { Reactor- } \\
\text { effluent }\end{array}$ & 4 \\
\hline Salicylate & Ammonium & MMSE & 10 & $\mathrm{mg} / \mathrm{l}$ & $\begin{array}{c}26 \text { times per } \\
\text { day }\end{array}$ & $\begin{array}{c}\text { Influent- } \\
\text { reactor- } \\
\text { effluent }\end{array}$ & $\begin{array}{c}\text { Reactor- } \\
\text { effluent }\end{array}$ \\
\hline Ferrous sulfate & Nitrite & MMSE & 10 & $\mathrm{mg} / \mathrm{l}$ & $\begin{array}{c}25 \text { times per } \\
\text { day }\end{array}$ & 4 \\
\hline Diazotization & Nitrite & MMSE & 40 & $\mathrm{mg} / \mathrm{l}$ & $\begin{array}{c}25 \text { times per } \\
\text { day }\end{array}$ & $\begin{array}{c}\text { Reactor- } \\
\text { effluent }\end{array}$ & 4 \\
\hline $\begin{array}{l}\text { Digestion, } \\
\text { distillation and } \\
\text { titration }\end{array}$ & TKN & MMSE & 25 & $\mathrm{mg} / \mathrm{l}$ & Twice a day & $\begin{array}{c}\text { Influent- } \\
\text { effluent }\end{array}$ & 4 \\
\hline
\end{tabular}

${ }^{*}$ minimum mean square error.

Table 5. General results of the blank and test reactor

\begin{tabular}{|l|c|c|c|c|c|c|c|c|c|c|}
\hline Reactor & $\begin{array}{c}\mathrm{COD} \\
\text { In } \\
{[\mathrm{mg} / \mathrm{l}]}\end{array}$ & $\begin{array}{c}\mathrm{TN} \\
\text { In } \\
{[\mathrm{mg} / \mathrm{l}]}\end{array}$ & $\begin{array}{c}\mathrm{OLR} \\
{\left[\mathrm{KgCOD} / \mathrm{m}^{3} \mathrm{~d}\right]}\end{array}$ & $\begin{array}{c}\mathrm{NLR} \\
{\left[\mathrm{KgN} / \mathrm{m}^{3} \mathrm{~d}\right]}\end{array}$ & $\begin{array}{c}\mathrm{SRT} \\
{[\mathrm{d}]}\end{array}$ & $\begin{array}{c}\mathrm{NO}_{2}^{-} \\
\text {Out } \\
{[\mathrm{mg} / \mathrm{l}]}\end{array}$ & $\begin{array}{c}\mathrm{NO}_{3}^{-} \\
\text {Out } \\
{[\mathrm{mg} / \mathrm{l}]}\end{array}$ & $\begin{array}{c}\mathrm{NH}_{4}^{+} \\
\text {Out } \\
{[\mathrm{mg} / \mathrm{l}]}\end{array}$ & $\begin{array}{c}\mathrm{COD} \\
\mathrm{Removal} \\
{[\%]}\end{array}$ & $\begin{array}{c}\mathrm{N} \\
\mathrm{Removal} \\
{[\%]}\end{array}$ \\
\hline Blank & 1000 & 80 & 0.67 & 0.054 & 20 & 0.07 & 9.54 & 1.70 & 95.5 & 86.25 \\
\hline $\begin{array}{l}\text { Test } \\
\text { Period 1 }\end{array}$ & 1000 & 80 & 0.67 & 0.054 & 20 & 0.19 & 7.25 & 0.79 & 94.8 & 88.75 \\
\hline $\begin{array}{l}\text { Test } \\
\text { Period 2 }\end{array}$ & 1000 & 80 & 0.67 & 0.054 & 20 & 0.21 & 5.9 & 0.72 & 94 & 91.43 \\
\hline $\begin{array}{l}\text { Test } \\
\text { Period 2 }\end{array}$ & 1000 & 147.5 & 0.67 & 0.1 & 20 & 0.18 & 14.3 & 0.81 & 92.2 & 88.81 \\
\hline $\begin{array}{l}\text { Test } \\
\text { Period 2 }\end{array}$ & 1000 & 222 & 0.67 & 0.15 & 20 & 0.42 & 25.5 & 1.90 & 90.03 & 86.48 \\
\hline $\begin{array}{l}\text { Test } \\
\text { Period 2 }\end{array}$ & 1500 & 80 & 1 & 0.054 & 20 & 0.35 & 13 & 1.94 & 86 & 80 \\
\hline $\begin{array}{l}\text { Test } \\
\text { Period 2 }\end{array}$ & 2200 & 80 & 1.5 & 0.054 & 20 & 0.56 & 17 & 2.1 & 81.8 & 73.75 \\
\hline
\end{tabular}

Effect of multiple filling events on total nitrogen (TN) removal efficiency

The blank reactor operation involved one anoxic filling event while influent COD and influent total nitrogen (TN) concentrations were $1000 \mathrm{mg} / \mathrm{l}$ and $80 \mathrm{mg} / \mathrm{l}$, respectively. The blank was operated at organic loading rate $(\mathrm{OLR})$ of $0.67 \mathrm{kgCOD} / \mathrm{m}^{3} \mathrm{~d}$ and nitrogen loading rate (NLR) of $0.054 \mathrm{kgN} / \mathrm{m}^{3} \mathrm{~d}$. The operation sequence consisted of the following steps: anoxic filling, aerobic reaction, anoxic reaction, second aerobic reaction, settling and discharging. The results showed that $\mathrm{TN}$ removal efficiency using equation 6 was $86.25 \%$ in the blank.

TN Removal efficiency $=\frac{N_{I N}-N_{\text {OUT }}}{N_{I N}} \times 100$

where:

TN Removal efficiency: Total nitrogen removal efficiency, $\%$.

$\mathrm{N}_{\text {IN }}$ : Nitrogen concentration in influent, $\mathrm{mg} / \mathrm{l}$.

$\mathrm{N}_{\text {OUT }}$ : Nitrogen concentration in effluent, $\mathrm{mg} / \mathrm{l}$.

No External or internal carbon source was added to blank reactor. Effluent nitrate concentration was 9.54 $\mathrm{mg} / \mathrm{l}$ in the blank. The presence of nitrate in effluent was mainly because of considering an aerobic stage at the end of the cycle. Consecutive aerobic and anoxic phases led to proper nitrogen removal efficiency but it could be improved by adding wastewater during each anoxic phase of intermittent aeration. In period 1 two anoxic filling events were carried out during a cycle of test reactor. Increasing the number of filling events from 1 to $2, \mathrm{TN}$ removal efficiency increased. In contrast to the blank, nitrate concentration in effluent reduced from 9.54 to $7.25 \mathrm{mg} / \mathrm{l}$ (Table 5). Also, effluent nitrite and ammonium concentrations decreased to 0.19 and $0.79 \mathrm{mg} / \mathrm{l}$, respectively. Considering three anoxic filling events during the reactor cycle in period 2 resulted in increasing efficiency of nitrogen removal. In the aerobic phase, nitrate was increased but the concentration of ammonium remains below the blank. Generally, lower concentrations of ammonium and nitrate could be found in the effluent. Feeding the reactor with third filling event, because of dilution, ammonium concentration was less than the influent. TN removal efficiency was $91.43 \%$ in period 2 which was $5.18 \%$ higher than the blank. This optimization was mainly because of adding wastewater as required organic matter for denitrification process. In contrast to the results of period 1 , effluent ammonium and nitrate decreased, simultaneously, but effluent nitrite increased by $0.07 \mathrm{mg} / \mathrm{l}$.

\section{Effect of multiple filling events on denitrification rate}

It was found that IA reactor with multiple filling events could have different anoxic phase durations. Therefor, the number of anoxic phases increased and specific denitrification rate $\left(\mathrm{SDNR}_{\mathrm{b}}\right)$ in IA reactor was investigated to find out how to achieve denitrification in shorter time. Heterotrophic $\mathrm{SDNR}_{\mathrm{b}}$ was calculated from equations 7,8 and $9^{4}$. In order to determine the kinetic coefficients of endogenous decay $\left(\mathrm{k}_{\mathrm{d}}\right)$ and yield $(\mathrm{Y})$ in period 1, Figure 4 was plotted and the coefficients of $Y$ and $\mathrm{k}_{\mathrm{d}}$ were obtained $0.46 \mathrm{mg} \mathrm{VSS} / \mathrm{mg} \mathrm{sCOD}$ and 0.051 $1 / \mathrm{d}$, respectively. In Figure 4 substrate utilization rate is given as $\mathrm{U}(\mathrm{mg} \mathrm{sCOD} / \mathrm{mg}$ VSS $\mathrm{d})$. Also, the kinetic coefficients in period 2 were obtained too. 


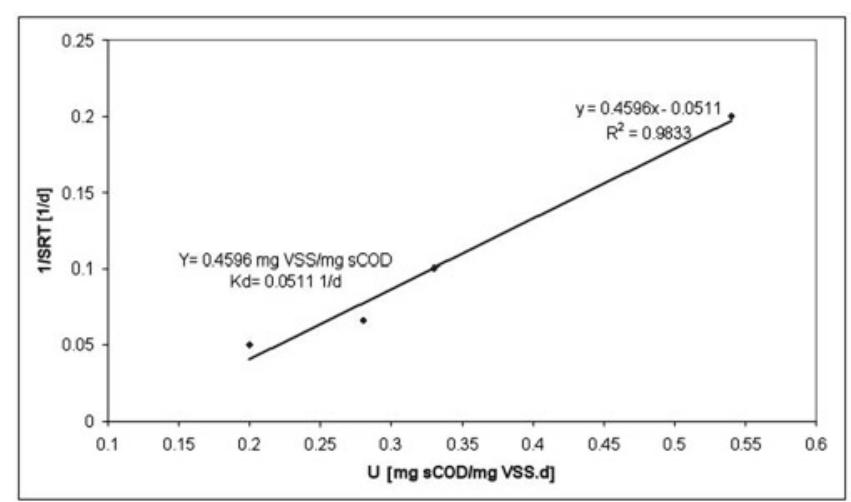

Figure 4. Determination of $\mathrm{K}_{\mathrm{d}}$ and $\mathrm{Y}$

$S D N R_{b}=\frac{0.175 A_{n}}{\left(Y_{\text {net }}\right) S R T}$

$A_{n}=1-1.42 Y+\frac{1.42\left(k_{d}\right)(Y)(S R T)}{1+\left(k_{d}\right) S R T}$

$Y_{n e t}=\frac{Y}{1+\left(k_{d}\right) S R T}$

where:

$\mathrm{SDNR}_{\mathrm{b}}$ : Heterotrophic specific denitrification rate, $\mathrm{mg}$ $\mathrm{NO}_{3}^{-} / \mathrm{mg}$ biomass,

$\mathrm{A}_{\mathrm{n}}$ : Net oxygen consumption rate, $\mathrm{mg} \mathrm{O}_{2} / \mathrm{mg}$ bCOD,

$\mathrm{Y}_{\text {net }}$ : Net efficiency of biomass (heterotrophic), mg $\mathrm{VSS} / \mathrm{mg}$ bCOD,

$\mathrm{k}_{\mathrm{d}}$ : Endogenous decay coefficient, $1 / \mathrm{d}$,

Y: Biomass yield coefficient, mg VSS/mg sCOD,

SRT: Solids retention time, d.

The effluent nitrate concentration for discharge to receiving waters must be below $50 \mathrm{mg} / \mathrm{l}$ according to department of environmental protection organization of Iran (DOE) standards ${ }^{\mathbf{2 6}}$. Considering influent and effluent nitrate concentration as well as nitrate concentration at the end of aerobic phase, duration of anoxic phases in period 1 and period 2 estimated 295 and 420 min, respectively. More ever, depending on the kinetic coefficients, anoxic phase duration was modified. The results should be equal to required nitrate removal which was calculated to find SDNRb. Table 5 shows that in contrast to period 1 , the operation with extended anoxic phase at OLR of $0.67 \mathrm{kgCOD} / \mathrm{m}^{3} \mathrm{~d}$ (period 2) would result in higher nitrate removal. This phenomenon was observed because of reduction of volatile suspended solids/biodegradable COD (VSS/bCOD) ratio which led to the increment of SDNRb. It was possible to decrease the anoxic phase duration, by changing SRT, to reach higher SDNRb. Also, Table 6 indicates that increasing the number of filling events, allowed shorter anoxic phases but the phases considered longer to reach required nitrate removal at NLR of $0.054 \mathrm{kgN} / \mathrm{m}^{3} \mathrm{~d}$. This improvement was mainly because of slight increasing of $\mathrm{k}_{\mathrm{d}}$. Furthermore, dilution after subsequent filling event was another reason for this optimization. Mardani et al. ${ }^{27}$

Table 6. The kinetic coefficient of kd for calculating $\mathrm{SDNR}_{\mathrm{b}}$

\begin{tabular}{|l|c|c|c|}
\hline Filling events & $\begin{array}{c}\mathrm{k}_{\mathrm{d}} \\
1 / \mathrm{d}\end{array}$ & $\begin{array}{c}\text { SRT } \\
{[\mathrm{d}]}\end{array}$ & $\begin{array}{c}\text { Anoxic phase } \\
{[\mathrm{min}]}\end{array}$ \\
\hline 2 & 0.045 & 15 & 420 \\
\hline 2 & 0.051 & 20 & 295 \\
\hline 3 & 0.089 & 25 & 295 \\
\hline 3 & 0.110 & 20 & 420 \\
\hline
\end{tabular}

reported similar results. They found that $\mathrm{k}_{\mathrm{d}}$ decreased with increasing of biomass level.

\section{OLR and NLR}

SBR was operated at OLR of $0.67 \mathrm{kgCOD} / \mathrm{m}^{3} \mathrm{~d}$ and NLR of $0.054 \mathrm{kgN} / \mathrm{m}^{3} \mathrm{~d}$ while COD and TKN in the influent were 1000 and $79 \mathrm{mg} / \mathrm{l}$, respectively. Figure 5 shows nitrate, nitrite and ammonium concentrations in the effluent at NLR of $0.054 \mathrm{KgN} / \mathrm{m}^{3} \mathrm{~d}$. To study the effect of higher OLRs and NLRs on the modified process, influent COD was increased step-wise in period 2. Table 5 indicates that COD removal efficiency decreased at higher OLRs. For example, when COD increased to $1500 \mathrm{mg} / \mathrm{l}$ nitrogen removal efficiency decreased to $80 \%$. Effluent nitrate, nitrite and ammonium concentrations increased to $13,0.35$ and $1.94 \mathrm{mg} / \mathrm{l}$, respectively, at OLR of $1 \mathrm{kgCOD} / \mathrm{m}^{3} \mathrm{~d}$ but the concentrations met the standards. Furthermore, intermittently aerated reactor with 3 filling events was operated at OLR of $1.5 \mathrm{kgCOD} / \mathrm{m}^{3} \mathrm{~d}$. Effluent nitrate, nitrite and ammonium concentrations increased to $17,0.56$, and $2.1 \mathrm{mg} / \mathrm{l}$, respectively. Although these concentrations met the effluent standards, nitrogen removal efficiency decreased from 91.43 to $73.75 \%$.

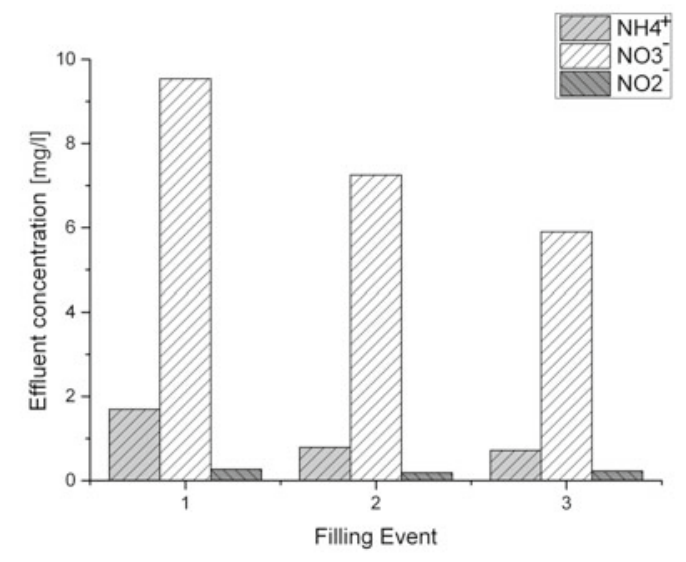

Figure 5. The effluent concentration of nitrate, nitrite and ammonium at NLR of $0.054 \mathrm{KgN} / \mathrm{m}^{3} \mathrm{~d}$

The effect of higher influent TN on nitrogen removal efficiency was also studied in period 2. Influent TN was almost equal to influent TKN. Influent TKN involved $50 \mathrm{mg} / \mathrm{l}$ ammonium that should be removed. Meanwhile, high effluent nitrate concentration was not allowable. The effluent nitrate was $14.3 \mathrm{mg} / \mathrm{l}$ at NLR of $0.1 \mathrm{kgN} /$ $\mathrm{m}^{3} \mathrm{~d}$ (influent $\mathrm{TN}$ of $147.5 \mathrm{mg} / \mathrm{l}$ ). Increasing NLR to 0.15 $\mathrm{kgN} / \mathrm{m}^{3} \mathrm{~d}$ decreased nitrogen removal efficiency to $86.48 \%$ and effluent nitrate, nitrite and ammonium concentrations were measured $25.5,0.42$, and $1.90 \mathrm{mg} / \mathrm{l}$, respectively. High OLRs and NLRs could be dominant factors in loss of TN removal efficiency in full-scale reactors in which SBR would be operated at higher loading rates. It was found that the sensitivity of the modified reactor to OLR is more than NLR. Thus, for example, changing $\mathrm{C} / \mathrm{N}$ ratio could optimize the efficiency in real size or industrial systems. Figure 6 a describes the concentration of effluent ammonium, nitrate and nitrite at different NLRs. Also, the effects of different OLRs on effluent nitrogen compounds are shown in Figure 6b. COD and TN removal decreased at higher OLR and NLR but the concentrations of nitrogen compounds in effluent 

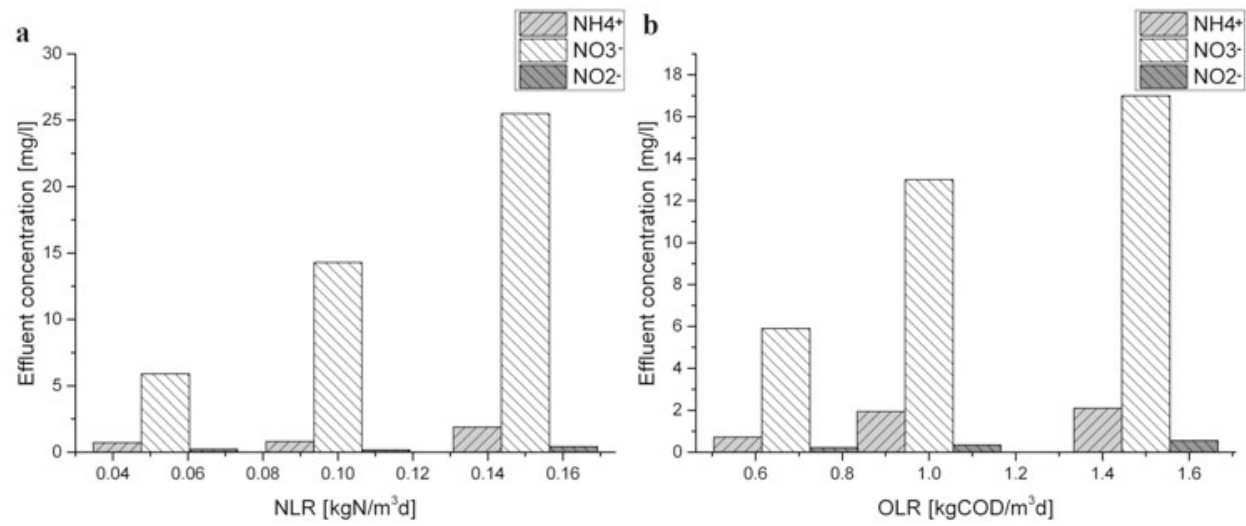

Figure 6. Effects of NLR and OLR on effluent parameters; a: NLR, b: OLR

were acceptable. The results showed the flexibility of the proposed method for nutrient removal. IA reactor with multiple filling events required more than one filling event and the effect of the number of filling events on effluent parameters depended on both OLR and NLR.

\section{Statistical analysis}

One-way analysis of variances (ANOVA) was used for statistical analysis of nitrogen removal efficiencies. Data distribution was normal according to Kolmogorov-Smirnov test and each test was repeated 4 times. Three groups of data (the blank, period 1 and period 2) were analyzed and the total sum of squares (SST) and the within group sum of squares (SSW) were calculated 59.547 and 5.757, respectively. The between groups sum of squares (SSB) value was obtained 53.790. Total degrees of freedom (df), the within groups $\mathrm{df}$ and the between groups $\mathrm{df}$ were 11, 9 and 2, respectively. Variance was calculated by dividing the total sums of squares of SSW and SSB by df. The ratio of variances $(\mathrm{F})$ was obtained 42.047 and the significance level of 0.05 was considered. The critical value of $\mathrm{F}\left(\mathrm{F}_{\text {crit }}\right)$ was obtained from $\mathrm{F}$-distribution table (10.110). The results were considered significant if $F$ value was greater than $F_{\text {crit }}$ value or significance level was less than 0.05 . These two decision factors occurred simultaneously $(42.047>10.110 ; 0<0.05)$.

\section{ORP and pH curve}

ORP and $\mathrm{pH}$ were considered as important parameters to determine the end point of nitrification and denitrification. Two critical points of ORP against time profile are important in nitrogen removal studies. Under aerobic condition, ORP curve rises until an inflection point. This critical point is called $\alpha$ and indicates the end of nitrification. Under anoxic condition, ORP curve is down trend until another inflection point. This critical point is called Nitrate Knee and indicates the end of denitrification. In $\mathrm{pH}$ profile Ammonia Valley and Nitrate Apex are two critical points. Under aerobic condition, $\mathrm{pH}$ curve decreases until an inflection point which is called Ammonia Valley and shows the end of nitrification. Adding carbon source, under anoxic condition, $\mathrm{pH}$ curve rises until another inflection point which is called Nitrate Apex and indicates the end of denitrification ${ }^{28}$. Anoxic phase is the most important step of proposed IA process with multiple filling events. ORP is a suitable control parameter for Nitrate Knee detection in SBR operation $^{28}$ ORP curve of a typical cycle of the reactor was analyzed in each period to evaluate nitrification and denitrification (Fig. 7). The results of ORP measurements, every 30 minutes, were plotted against time at NLR of $0.054 \mathrm{kgN} / \mathrm{m}^{3} \mathrm{~d}$. $\alpha$ Points in Figure 7 indicate the end of nitrification. The first $\alpha$ point could be observed after 215 minutes from the start of the cycle in the first aerobic phase of period 2 (Fig. 7b). The second and third $\alpha$ points occurred after 720 and $1260 \mathrm{~min}$ utes, respectively. Under anoxic condition, ORP curve descended until two Nitrate Knees. The first inflection point could be identified after 510 minutes under anoxic condition which was the first Nitrate Knee in period 2. The second one was recognized after 1000 minutes in second anoxic phase. This point occurred about one hour after the third filling event, but Nitrate Knee in Figure 7a (IA reactor with two filling events) was identified
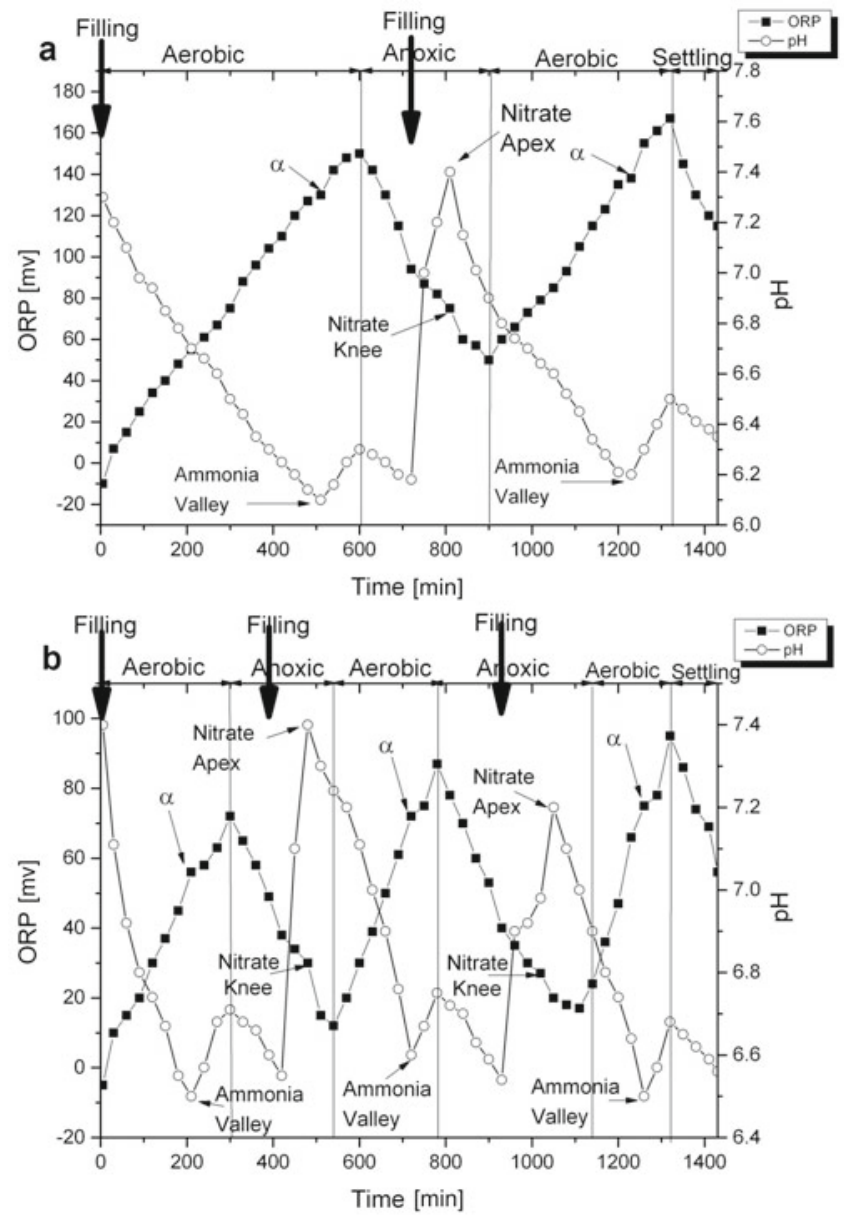

Figure 7. Variation of ORP and $\mathrm{pH}$ during a typical cycle; a: Period 1, b: Period 2 
about 90 minutes after second filling event. It would be observed that each Nitrate Knee point occurred about 60 minutes after each filling event of period 2. Accordingly, accumulated nitrate and nitrite was removed faster than period 1. Three filling events as well as consecutive aerobic and anoxic phases resulted in shorter time of nitrification and denitrification. The $\mathrm{pH}$ curve in Figure $7 \mathrm{a}$ and Figure $7 \mathrm{~b}$ contained two and three Ammonia Valley points, respectively. Ammonia Valley points in $\mathrm{pH}$ curve indicated the end of nitrification, and detection of these points was possible in periods 1 and 2. Two Nitrate Apex points were identified after 480 and 1050 minutes from the start of the cycle in period 2. These inflection points in $\mathrm{pH}$ against time profile showed that accumulated nitrogen oxides were successfully converted to nitrogen gas in each anoxic phase. Remained nitrate after last Ammonia Valley (under aerobic condition) was consumed in the next cycle of the reactor. Besides, it was observed that Ammonia Valley points and $\alpha$ points occurred simultaneously. It should be mentioned that sudden increasing of $\mathrm{pH}$ in Figure 7 (in anoxic phases) happened because of adding wastewater as internal carbon source.

\section{Nitrate, nitrite and ammonium evolution}

A typical cycle of IA reactor operation at OLR of $0.67 \mathrm{kgCOD} / \mathrm{m}^{3} \mathrm{~d}$ and NLR of $0.054 \mathrm{kgN} / \mathrm{m}^{3} \mathrm{~d}$ were analyzed to study the evolution of nitrogen compounds (Fig. 8). Nitrate, nitrite, and ammonium concentrations were analyzed every 60 minutes during 24-h cycle of the reactor operation. Figure 8 a describes that under first aerobic phase (10 hours) nitrate concentration increased to $27.3 \mathrm{mg} / \mathrm{l}$ while ammonium level decreased to $5 \mathrm{mg} / \mathrm{l}$. Ammonium level reduction was because of nitrification as well as oxidation of ammonium to nitrite and then nitrate. Maximum concentration of nitrite was observed at the 4 th hour of the cycle $(1.9 \mathrm{mg} / \mathrm{l})$. This concentration of nitrite was almost detected when nitrate curve met ammonia curve and indicated nitrification process. Under anoxic condition, from 10th to 15 th hour of the cycle, nitrate level was reduced and finally it was removed from the reactor as nitrogen gas. Adding wastewater in anoxic phase, nitrogen compounds evolution was considerable. Figure 8a shows that by anoxic feeding at the 12th hour of the cycle, ammonium concentration increased suddenly to $20.2 \mathrm{mg} / \mathrm{l}$. Nitrate level was decreased after second filling event because of dilution in the reactor. In second aerobic phase, (from 15 th to 22 th hour) reduction of ammonium concentration from 21.9 to $1.12 \mathrm{mg} / \mathrm{l}$ which led to slight increment of nitrate was observed. Nitrate level was $8 \mathrm{mg} / \mathrm{l}$ at the end of aeration time and finally reduced to $7.25 \mathrm{mg} / \mathrm{l}$. At the end of second aerobic phase nitrite and ammonium concentration were 0.22 and $1.12 \mathrm{mg} / \mathrm{l}$, respectively. Effluent nitrate and ammonium decreased to 0.19 and $0.79 \mathrm{mg} / \mathrm{l}$, respectively. Also, nitrogen compounds evolution in period 2 (Figure $8 b$ ) indicated that ammonium and nitrate were removed, simultaneously, by IA-SBR. It could be observed that maximum nitrate concentration of $37 \mathrm{mg} / \mathrm{l}$ (at the 5 th hour of the cycle) resulted in complete denitrification. Effluent nitrate level of $5.9 \mathrm{mg} / \mathrm{l}$ was determined which was the lowest effluent nitrate level. Multiple filing events provided more soluble COD (sCOD) when heterotrophic bacteria required carbon source for nitrate reduction. Furthermore, considering two anoxic phases and a 24-h cycle, elimination of remained nitrate of previous cycle or previous aerobic phase is feasible. It was shown that the increment of the number of filling events in IA reactor improved simultaneous removal of ammonium and nitrate.

\section{CONCLUSIONS}

Biological nitrogen removal in IA-SBR without using external carbon source was studied. Complete nitrification and denitrification could be achieved by filling the reactor under anoxic condition. The proposed method with multiple filling events resulted in high nitrogen removal efficiency. It was found that by increasing the number of filling events in a single tank, nitrogen removal efficiency would be acceptable. At the start of the cycle nitrification was achieved under aerobic condition using influent ammonium. Two aerobic phases was considered in the reactor cycle to figure out aerobic-anoxic-aerobic sequence. Nitrate removal occurred after each anoxic phase. Increasing the number of anoxic filling events in a cycle optimized simultaneous ammonium and nitrate removal. Ammonia Valley points and $\alpha$ points almost occurred simultaneously in the $\mathrm{pH}$ and ORP profiles. Also, Nitrate Knee and Nitrate Apex were identified at the same time. These critical points have demonstrated the feasibility of providing nitrification and denitrification in a single reactor with 3 filling events. Additionally, it was found that the value of heterotrophic $\mathrm{SDNR}_{\mathrm{b}}$ was
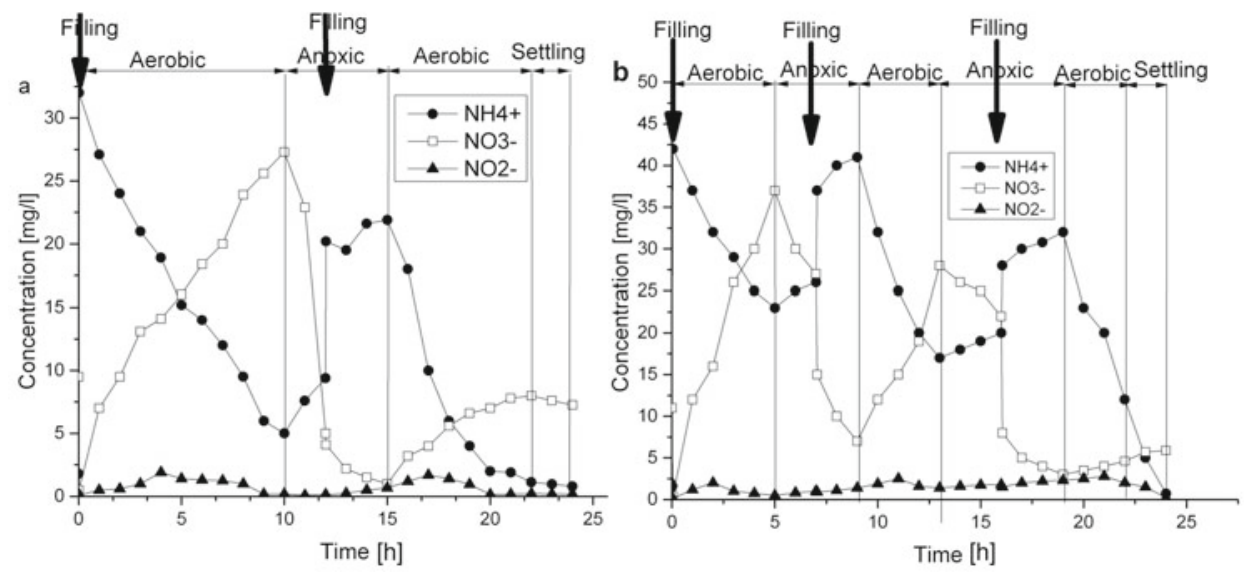

Figure 8. Profiles of nitrogen compounds concentrations in a typical cycle; a: Priod1, b: Period 2 
higher in the operation with 3 anoxic phases. This increment effected on the considered duration of anoxic phase and improved TN removal efficiency, significantly. Considering multiple filling events in a real sewage treatment plant could be more difficult than laboratory-scale SBR but the process would be cost-beneficial because no external carbon source is needed. Nitrogen removal efficiency was decreased at higher NLRs or higher OLRs but the effluent nitrate, nitrite and ammonium concentrations met the recommended standards for discharge.

\section{NOMENCLATURE}

$\mathrm{A}_{\mathrm{n}}$ - net oxygen consumption rate, $\mathrm{mg}_{2} / \mathrm{mg}$ bCOD ANAMMOX - anaerobic ammonium oxidation

ANOVA - analysis of variances

$\mathrm{AOB}$ - ammonium oxidizing bacteria

BNR - biological nutrient removal

$\mathrm{C} / \mathrm{N}$ - carbon/nitrogen ratio

CANON - completely autotrophic nitrogen removal over nitrite

COD - chemical oxygen demand, $\mathrm{mg} / \mathrm{l}$

df - degrees of freedom

DO - dissolved oxygen, $\mathrm{mg} / \mathrm{l}$

DOE - department of environmental protection organization of Iran

$\mathrm{F}$ - the ratio of variances

$\mathrm{F}_{\text {crit }}$ - critical value of $\mathrm{F}$

HRT - hydraulic retention time, $\mathrm{h}$

IA - intermittently aerated

IA-SBR - intermittently aerated sequencing batch reactor

$\mathrm{k}_{\mathrm{d}}-$ endogenous decay coefficient, $1 / \mathrm{d}$

$\mathrm{M}$ - the number of filling events during one cycle

MMSE - minimum mean square error

$\mathrm{N}_{\mathrm{EF}}$ - nitrogen concentration in the effluent, $\mathrm{mg} / \mathrm{l}$

$\mathrm{N}_{\mathrm{IN}}$ - nitrogen concentration in the influent, $\mathrm{mg} / \mathrm{l}$

NLR - nitrogen loading rate, $\mathrm{kg} \mathrm{N} / \mathrm{m}^{3} \mathrm{~d}$

NOB - nitrite oxidizing bacteria

OLAND - oxygen-limited autotrophic nitrificationdenitrification

OLR - organic loading rate, $\mathrm{kg} \mathrm{COD} / \mathrm{m}^{3} \mathrm{~d}$

ORP - oxidation-reduction potential, $\mathrm{mV}$

SBR - sequencing batch reactor

$\mathrm{SDNR}_{\mathrm{b}}$ - heterotrophic specific denitrification rate, $\mathrm{mg}$

$\mathrm{NO}_{3}^{-} / \mathrm{mg}$ biomass

SNAD - simultaneous nitrification-anammoxdenitrification

SND - simultaneous nitrification and denitrification

SRT - solids retention time, $\mathrm{d}$

SSB - the between groups sum of squares

SST - total sum of squares

SSW - the within group sum of squares

TKN - total kjeldahl nitrogen, $\mathrm{mg} / \mathrm{l}$

$\mathrm{TN}$ - total nitrogen

TSS - total suspended solids, $\mathrm{mg} / \mathrm{l}$

$\mathrm{U}$ - substrate utilization rate, $\mathrm{mg} \mathrm{sCOD/mg} \mathrm{VSS} \mathrm{d}$

VSS - volatile suspended solids, $\mathrm{mg} / \mathrm{l}$

$\mathrm{V}_{\mathrm{F}} / \mathrm{V}_{\mathrm{T}}$ - the ratio between fill volume and total reactor volume

WWTP - wastewater treatment plant

$\mathrm{Y}$ - yield coefficient, mg VSS/mg sCOD

$\mathrm{Y}_{\text {net }}$ - net efficiency of biomass (heterotrophic), mg $\mathrm{VSS} / \mathrm{mg}$ bCOD

\section{Greek letters}

$\alpha$ - inflection point of ORP profile under aerobic condition

\section{LITERATURE CITED}

1. Ferreira, J.G., Andersen, J.H., Borja, A., Bricker, S.B., Camp, J., Cardoso Da Silva, M., Garcés, E., Heiskanen, A.S., Humborg, C., Ignatiades, L., Lancelot, C., Mensegun, A., Tett, P., Hoepffner, N. \& Claussen, U. (2011). Overview of eutrophication indicators to assess environmental status within the European Marine Strategy Framework Directive. Estuar. Coast. Shelf. S. 93(2), 117-131. DOI: 10.1016/j.ecss.2011.03.014.

2. Chislock, M.F., Doster, E., Zitomer, R.A. \& Wilson, A.E. (2013). Eutrophication: causes, consequences, and controls in aquatic ecosystems. Nat. Educ. Know. 4(4), 10.

3. Yanga, S., Yang, F., Fu, Z., Wang, T. \& Lei, R. (2010). Simultaneous nitrogen and phosphorus removal by a novel sequencing batch moving bed membrane bioreactor for wastewater treatment. J. Hazard. Mater. 175, 551-557. DOI: 10.1016/j.jhazmat.2009.10.040.

4. Metcalf \& Eddy. (2003). Wastewater engineering: Treatment and reuse (4th ed.). Boston, USA: McGraw-Hill.

5. Zhou, Y., Oehmen, A., Lim, M., Vadivelu, V. \& NG, W.J. (2011). The role of nitrite and free nitrous acid (FNA) in wastewater treatment plants. Water Res. 45(15), 4672-4682. DOI: 10.1016/j.watres.2011.06.025.

6. Ding, D., Feng, C., Jin, Y., Hao, C., Zhao, Y. \& Suemura, T. (2011). Domestic sewage treatment in a sequencing batch biofilm reactor (SBBR) with an intelligent controlling system. Desalination 276(1-3), 260-265. DOI: 10.1016/j.desal.2011.03.059.

7. Jungles, M.K., Campos, J.L. \& Costa, R.H.R. (2014). Sequencing batch reactor operation for treating wastewater with aerobic granular sludge. Braz. J. Chem. Eng. 31(1), 27-33. DOI: http://dx.doi.org/10.1590/S0104-66322014000100004

8. United States Environmental Protection Agency (USEPA). (1999). Wastewater technology fact sheet: Sequencing batch reactors, EPA 832-F-99-073.

9. Singh, M. \& Srivastava, R.K. (2011). Sequencing batch reactor technology for biological wastewater treatment: a review. Asia-Pac. J. Chem. Eng. 6(1), 3-13. DOI: 10.1002/apj.490.

10. Venkata Mohan, S., Chandrashekara Rao, N., Krishna Prasad, K., Madhavi, B.T.V. \& Sharma, P.N. (2005). Treatment of complex chemical wastewater in a sequencing batch reactor (SBR) with an aerobic suspended growth configuration. Process Biochem. 40(5), 1501-1508. DOI: 10.1016/j.procbio.2003.02.001.

11. Lim, J.W., Seng, C.E., Lim, P.E., Ng, S.L. \& Ahmed Sujari, A.N. (2011). Nitrogen removal in moving bed sequencing batch reactor using polyurethane foal cubes of various sizes as carrier materials. Bioresour. Technol. 102(21), 9876-9883. DOI: 10.1016/j.biortech.2011.08.014.

12. Uemoto, H., Shoji, T. \& Uchida, S. (2014). Biological filter capable of simultaneous nitrification and denitrification for Aquatic Habitat in International Space Station. Life Sci. Space Res. 1, 89-95. DOI: 10.1016/j.1ssr.2014.02.002.

13. Kampschreur, M.J., Temmink, H., Kleerebezem, R., Jetten, M.S.M. \& van Loosdrecht, M.C.M. (2009). Nitrous oxide emission during wastewater treatment. Water Res. 43(17), 4093-4103. DOI: 10.1016/j.watres.2009.03.001.

14. Guo, J., Yang, Q., Peng, Y., Yang, A. \& Wang, H. (2007). Biological nitrogen removal with real-time control using step-feed SBR technology. Enzyme Microb. Tech. 40(6), 1564-1569. DOI: 10.1016/j.enzmictec.2006.11.001.

15. Kulkarni, P. (2013). Nitrophenol removal by simultaneous nitrification denitrification (SND) using T. pantotropha in sequencing batch reactors (SBR). Bioresour. Technol. 128, 273-280. DOI: 10.1016/j.biortech.2012.10.054. 
16. United States Environmental Protection Agency (USEPA). (2013). Wastewater treatment fact sheet: external carbon sources for nitrogen removal, EPA 832-F-13-016.

17. Vives, M.T. (2004). SBR Technology for Wastewater Treatment: Suitable Operational Conditions for a Nutrient Removal. Unpublished doctoral dissertation, University of Girona, Girona, Spain.

18. Jun, L., Tao, Y., Xue-bin, L., Li-min, W. \& Hui, Z. (2013). Effect of anaerobic time on biological nitrogen removal in a modified SBR. Desal. Water Treat. 51(19-21), 3691-3699. DOI: 10.1080/19443994.2013.782047.

19. Won, S.G., Jeon, D.Y, Kwag, J.H., Kim, J.D. \& Ra, C.S. (2015). Nitrogen removal from milking center wastewater via simultaneous nitrification and denitrification using a biofilm filtration reactor. Asian Aus. J. Anim. Sci. 28(6), 896-902. DOI: http://dx.doi.org/10.5713/ajas.14.0839.

20. Wang, J., Peng, Y., Wang, S. \& Gao, Y. (2008). Nitrogen removal by simultaneous nitrification and denitrification via nitrite in a sequencing hybrid biological reactor. Chin. J. Chem. Eng. 16(5), 778-784. DOI: 10.1016/S1004-9541(08)60155-X.

21. Whitacre, D.M. (Ed.). (2012). Reviews of environmental contamination and toxicology. Springer.

22. Joss, A., Salzgeber, D., Eugster, J., König, R., Rottermann, K., Burger, S., Fabijan, P., Leumann, S., Mohn, J. \& Siegrist, H. (2009). Full-scale nitrogen removal from digester liquid with partial nitritation and anammox in one SBR. Environ. Sci. Technol. 43(14), 5301-5306. DOI: 10.1021/es900107w.

23. Su, J.J., Chang, Y.C. \& Huang, S.M. (2014). Ammonium reduction from piggery wastewater using immobilized ammonium-reducing bacteria with a full-scale sequencing batch reactor on farm. Water Sci. Technol. 69(4), 840-846. DOI: $10.2166 /$ wst.2013.787.

24. Wett, B., Omari, A., Podmirseg, S.M., Han, M., Akintayo, O., Gómez Brandón, M., Nyhuis, G., Murthy, S., Bott, C., Hell, M., Takács, I., Nyhuis, G. \& O’Shaughnessy M. (2013). Going for mainstream deammonification from bench-to full scale for maximized resource efficiency. Water Sci. Technol. 68(2), 283-289. DOI: 10.2166/wst.2013.150

25. APHA. (1998). Standard methods for the examination of water and wastewater (20th ed.). Washington DC, USA: American Public Health Association/American Water Works Association/Water Environment Federation,

26. Research department of environmental protection organization of Iran (DOE). (1994). Iranian effluent discharge standards. Tehran, Iran.

27. Mardani, S., Mirbagheri, A., Amin, M.M. \& Ghasemian, M. (2011). Determination of biokinetic coefficients for activated sludge processes on municipal wastewater. Iran. J. Environ. Health Sci. Eng. 8(1), 25-34. DOI: 10.4103/2277-9183.170702.

28. Won, S.G. \& Ra, C.S. (2011). Biological nitrogen removal with a real-time control strategy using moving slope changes of $\mathrm{pH}(\mathrm{mV})$ - and ORP -time profiles. Water Res. 45(1), 171-178. DOI: 10.1016/j.watres.2010.08.030. 